\title{
STAROŚĆ, CZYLI „NIEMOŻNOŚĆ, ZDEZAKTUALIZOWANIE, ZBLAKNIĘCIE”, JAKO LEITMOTIV W TRYPTYKU SYLWICZNYM ORAZ AUTOKOMENTARZaCH TADEUSZa KonWICKIEgO
}

Cały dorobek artystyczny Tadeusza Konwickiego jest silnie naznaczony jego osobistymi przeżyciami. W każdym dziele można odnaleźć te same motywy, sytuacje, postacie oraz opisy przyrody. Najczęściej Konwicki powracał do tematu drugiej wojny światowej, która wtargnąwszy w 1939 roku do Kolonii Wileńskiej — „małej ojczyzny pisarza" - nieodwracalnie zmieniła jego postrzeganie świata.

Tadeusz Konwicki, opuszczając swoje rodzinne strony w maju 1945 roku, zabrał z sobą i wwiózł do Polski ogromny bagaż doświadczeń, które następnie rozpakowywał przez wiele lat. Według autora monografii na temat twórczości filmowej artysty — Jacka Fuksiewicza: „[...] Każdy kolejny utwór [Konwickiego] był w jakiejś mierze próbą otrząśnięcia się, wyzwolenia od ciężaru [wojny]"1. Podobnie twierdzą także i inni interpretatorzy ${ }^{2}$ prozy oraz filmów artysty. Powodem nieustającego powracania Konwickiego do wydarzeń z 1944 roku było poczucie zdrady oraz oszukania:

Konwicki wstąpił do partyzantki, by walczyć za swoją ojczyznę. [...] dopiero później odkrył politykę: wtedy, gdy w 1944 front przetaczał się na zachód, a partyzantka antyniemiecka przekształca się niekiedy w partyzantkę antyradziecką. Za tę zdobytą w lesie lekcję polityki i historii płaci, podobnie jak wielu z jego pokolenia, wysoką cenę. [...] Mijają lata a Konwicki wciąż boryka się ze swoją zdradą [...] $]^{3}$.

Walka Konwickiego z kompleksem zdrady rozgrywa się przede wszystkim na kartach jego powieści, w których skumulował oraz tłumaczył swoje lęki i obsesje.

Po wydarzeniach zawiązanych z II wojną światową los w dalszym ciągu nie oszczędzał młodego, startującego pisarza, bowiem życie w Polsce, dokładniej w Warszawie — stolicy

\footnotetext{
* Katarzyna Ossowska - absolwentka filologii polskiej i kulturoznawstwa, doktorantka w Katedrze Literatury Staropolskiej i Nauk Pomocniczych Uniwersytetu Łódzkiego. Jej główne zainteresowania badawcze obejmują twórczość Tadeusza Konwickiego, relacje z XV/XVI-wiecznych podróży do Jerozolimy autorstwa Polaków, geopoetykę oraz PR i marketing wydawnictwa.

${ }^{1}$ J. Fuksiewicz, Tadeusz Konwicki, Warszawa 1967, s. 15-16 (w nawiasie kwadratowym podaje się dopowiedzenia autorki tekstu).

${ }^{2}$ Do najważniejszych należą: Jan Walc, Jacek Fuksiewicz, Stanisław Bereś, Judith Arlt, Przemysław Kaniecki, Barbara Giza oraz Tadeusz Sobolewski.
}

${ }^{3}$ J. Fuksiewicz, dz. cyt., s. 15-16. 
komunistycznego państwa — nie było pozbawione trudnych wyborów. Konwicki zdecydował się uwierzyć w rolę socrealistycznej literatury, w której duchu napisał, na przykład Przy budowie. Wielu badaczy twierdzi jednak, że: „[...] Uwierzenie w sens i misję realizmu socjalistycznego, tak jak go wówczas pojmowano, przejęcie się nim i pisanie w jego duchu nie było sprawą łatwą” ${ }^{\prime}$. Pomimo to Konwicki chciał wierzyć w promowany przez władzę system, a wyrazem tego jest kilka tekstów $\mathrm{z}$ tamtego okresu.

„Zapaść, czyli odwrócenie się od postulatów socrealistycznej literatury, nastąpiła u Konwickiego po wydarzeniach roku $1956^{6}$. W październiku tego roku doszło do poważnych akcji strajkowych oraz demonstracji. Czynnikiem ewokującym takie zachowanie społeczeństwa było poczucie niezadowolenia z komunistycznych rządów ${ }^{7}$. Rzeczywistość po raz kolejny zniweczyła dobre intencje Konwickiego. Drugi raz w swoim życiu pisarz poczuł się oszukany przez „historię”, co nieodwracalnie wpłynęło na jego dalsze działania artystyczne. Od tamtej pory celem głównym Konwickiego stało się odnajdywanie prawdziwych wartości, prawdy słowa - w ogóle prawdy, co z kolei doprowadziło pisarza do prozy quasi-biograficznej, a w rezultacie sylwy współczesnej.

Pierwszą sylwą był wydany w 1976 roku Kalendarz i klepsydra — część inaugurująca tryptyk składający się jeszcze ze Wschodów i zachodów księżyca oraz Nowego Świata i okolic. Prawie równocześnie z opublikowaniem zamykającej cykl sylwy ukazał się wywiad-rzeka - Pót wieku czyśćca ${ }^{10}$. Sesje rozmów z Tadeuszem Konwickim przeprowadził na przełomie wiosny i lata 1984 roku Stanisław Bereś. Opublikowany zapis stał

\footnotetext{
${ }^{4}$ Tamże, s. $15-16$.

${ }^{5}$ Przede wszystkim należy wymienić powieść Przy budowie z 1950 roku oraz zwiastującą już zmiany w sposobie postrzegania przez Konwickiego socjalistycznego ustroju Godzinę smutku z 1954 roku.

${ }^{6}$ Były to wydarzenia polskiego Października, które okazały się początkiem rozpadu systemu. Nawoływanie do wprowadzenia zmian w Polsce, oraz ostra krytyka stalinizmu, płynąca podczas obrad VIII Plenum z ust Władysława Gomułki, nie tylko sprowokowała ludzi do spotykania się i zrzeszania na wiecach, ale także odbiła się bolesnym echem w sumieniach tych, którzy chcieli „wierzyć”. (A. Magierska, W poszukiwaniu polskiego Października, [w:] Październik 1956 roku. Początek erozji systemu, red. M. Jabłonowski, S. Stępka, Pułtusk 2007, s. 95-126.).

${ }^{7}$ Protest radomski przeciwko ogłoszeniu 24 czerwca 1976 roku przez premiera Jaroszewicza „propozycji zmian struktur cen” towarów konsumpcyjnych — niektórych nawet o sto procent — „[...] był wydarzeniem wielkiej wagi, ponieważ stanowił dramatyczne zakończenie sześcioletniego — trwającego od krwawego stłumienia strajków na Wybrzeżu w 1970 roku, po których Władysława Gomułkę na stanowisku I sekretarza zastąpił Gierek — okresu względnej stabilizacji. [...]”. Strajki wybuchły z rana następnego dnia w zakładach przemysłowych. Pierwsze przejawy protestu ujawniły się w Radomiu w zakładach Waltera. To także w tym mieście, doszło do walk z protestującymi w wyniku interwencji sił bezpieczeństwa. „[...] Około godziny 9.00, 1453 silnie uzbrojonych funkcjonariuszy sił bezpieczeństwa ostatecznie spacyfikowało protest [...]”. (D. Morgan, Konflikt pamięci. Narracje radomskiego Czerwca 1976, Warszawa 2004, s. 18-33).

${ }^{8}$ T. Konwicki, Wschody i zachody księzyca, wyd. 2, Warszawa 1990; wyd. 1 - II obieg, 1982.

${ }^{9}$ Tenże, Nowy Świat i okolice, Warszawa 1986.

${ }^{10}$ S. Nowicki, Pót wieku czyśćca. Rozmowy z Tadeuszem Konwickim, Londyn 1986, Aneks; Warszawa [poza cenzurą 1986]; Warszawa 1990.
} 
się nieocenionym źródłem wiedzy na temat życia i twórczości artysty, a także bezcenną wskazówką do poprawnego zrozumienia niektórych z jego rozwiązań literackich. Po wywiadzie przeprowadzonym przez Beresia nastąpiły kolejne, które także zostały opublikowane: Pamiętam, że byto goraco ${ }^{11}$ (rozmowę zainaugurowali Katarzyna Bielas i Jacek Szczerba) oraz W pośpiechu ${ }^{12}$ (gdzie inicjatorem spotkań był Przemysław Kaniecki).

W nowym dla twórczości pisarza okresie, otwartym Kalendarzem i klepsydra, prymarnym i jawnym tematem stały się jego osobiste doświadczenia i refleksje. We wszystkich snutych przez pisarza „ufabularyzowanych” przemyśleniach stale przewija się motyw starości, a dokładniej — starzenia się. Jest to rzecz dziwna, zważywszy na fakt, że w czasie wydania pierwszej z sylw Konwicki miał równo 50 lat — czy jest to już wiek, w którym człowiek zaczyna „odliczać dolegliwości” zbliżające go do „końca”, do śmierci? Być może tak? Możliwe, że zaważyła na tym liczba i intensywność zebranych przez pół wieku doświadczeń, a może był to dla pisarza pewnego rodzaju „fortel”, za którego pomocą mógł osiągnąć przewagę, wyższość w dialogu z „inteligentnym" czytelnikiem.

Do motywu starości Konwicki odwoływał się często w różnorodny sposób. „Starość" w jego prozie jest wielowymiarowa - nie odsyła jedynie do fizycznego przemijania, do biologicznego procesu starzenia, bowiem skorelowana z nią metaforyka często odnosi się także do procesu twórczego. Ma również istotne znaczenie w refleksjach na temat kondycji intelektualnej człowieka XX wieku, ludzkiego losu oraz jego sensu. Można wymienić kilka sytuacji literackich oraz pozaartystycznych, w których autor Kalendarza i klepsydry świadomie zakładał maskę starca lub jedynie przywoływał kwestie związane z ostatnim etapem ludzkiej egzystencji.

Konwicki poruszał temat starości zawsze, gdy opisywał pierwsze lata życia w powojennej Polsce. Opowiadał o sobie i swoich rówieśnikach, którzy tak samo jak i on cierpieli na kompleks „młodziankowości”:

[...] Moje pokolenie wstydziło się młodości ${ }^{13}$. Mając dwadzieścia lat, zapuszczaliśmy wąsy, wkładaliśmy pilśniowe kapelusze, stroiliśmy się w staroświeckie marynarki. Młodość uchodziła za coś krępującego, niepełnego, nawet ułomnego. Trzeba było się z nią ukrywać $[\ldots]^{14}$;

[...] Mój kolega Ścibor-Rylski, który [...] był chyba młodszy ode mnie, musiał zapuścić wąsy, żeby dodać swej sylwetce powagi. Chcąc nadrobić brak lat, chodziliśmy w kapeluszach i sakpaltach, takich płaszczach prawie do kostek. Żyliśmy, a przynajmniej ja żyłem, w kompleksie młodziankowości $[\ldots]^{15}$.

Starość była dla nich — dosłownie — kostiumem, za którym skrywali swój młody wiek. Absolutnie nie przystawał on do siły i różnorodności zdobytych przez nich

\footnotetext{
${ }^{11}$ K. Bielas, J. Szczerba, Pamiętam, że byto goraco. Rozmowy z Tadeuszem Konwickim, Kraków 2001.

${ }^{12}$ P. Kaniecki, W pośpiechu. Tadeusz Konwicki, Wołowiec 2011.

${ }^{13}$ Wszystkie podkreślenia w cytatach z dzieł Konwickiego, jak i z opracowań badaczy są moje - K. O.

${ }^{14}$ Tamże, s. 443.

${ }^{15}$ K. Bielas, J. Szczerba, dz. cyt., s. 237.
} 
doświadczeń. Wewnętrznie Konwicki oraz jego rówieśnicy czuli się starszymi niż byli w rzeczywistości, niż wskazywał na to ich wygląd:

[...] Jest taki wiersz Asnyka, w którym on mówi do panienki, że jest stary. A ma trzydzieści siedem lat. [...] myśmy bardzo wcześnie zaczęli. Dzisiaj, mając trzynaście lat, byłbym bez mała bobaskiem wożonym w wózku. Ja w tym wieku byłem w 1939 roku w oddziałach paramilitarnych ochrony kolei. [...] Gdy miałem szesnaście lat, podlegałem obowiazkowi pracy, zasuwałem pod batem 10-12 godzin. [...] jako dziewiętnastolatek, byłem redaktorem technicznym w „Odrodzeniu” [...] ${ }^{16}$.

[...] - Przecież wie pan, że należę do przedwcześnie postarzałego pokolenia. Wspomniałem chyba, że mając trzynaście lat posiadałem pistolet - straszak na amunicję flowerową, $\mathbf{z}$ którego można było zabić człowieka $[\ldots]^{17}$.

Konwicki, będąc trzynastoletnim chłopcem, został zmuszony przez „historię” do tego, aby nagle wydorośleć, stać się mężczyzną. Musiał nie tylko chronić samego siebie przed niebezpieczeństwem płynącym ze strony rosyjskiej oraz niemieckiej, ale także spoczywała na nim odpowiedzialność za los wrogów oraz współtowarzyszy broni. Konwicki mógł decydować o życiu drugiego człowieka.

Kontrastem dla „starości” pochodzącej ze wspomnień Konwickiego jest „starość” - prawdziwa - fizjologiczna. Stała się ona niewątpliwie leitmotivem tryptyku sylwicznego, w którym pisarz w sposób bezpośredni informował czytelników o swoim „sędziwym wieku”:

[...] Żegnaj, literaturo. Mówi do was od tej chwili starszy pan (Kalendarz, s. 171)

[...] Oczywiście nikt mi nie uwierzy, ale naprawdę byłem zawsze przekonany, że nigdy się nie zestarzeję, że ominie mnie starość. [...] Lecz niestety, przyszedł wreszcie dzień, kiedy znalazł się pierwszy młodszy ode mnie. Później takich sytuacji, pieszczochów przybywało coraz więcej i w końcu okazało się, że w każdej sytuacji, jaka by się zdarzyła, jestem seniorem (Kalendarz, s. 67);

[...] Starzec Konwicki, ten czarownik z Puszczy Rudnickiej [...] (Wschody, s. 36) ${ }^{19}$;

[...] Jak przystało na prawdziwego literata w starszym wieku, powinienem wspomnieć o swojej chorobie. Że leżę oto w swojej nyży powalony niemocno zapaleniem gardła (Wschody, s. 139).

Samo deklarowanie o starczym stanie nie byłoby jednak wystarczające, dlatego też uzasadnione zdają się być wprowadzone przez Konwickiego opisy rzeczywistości uzupełniające i potwierdzające wizerunek starca. Można je podzielić na trzy grupy: 1. opisy pogarszającego się stanu zdrowia literata; 2 . niełatwo przebiegającego procesu twórczego; 3. starzejącego się otocznia Konwickiego:

\footnotetext{
${ }^{16}$ Tamże, s. s. 236-237.

${ }^{17}$ S. Bereś, Pót wieku czyśćca. Rozmowy z Tadeuszem Konwickim, Kraków 2003, s. 188.

${ }^{18}$ T. Konwicki, Kalendarz i klepsydra, Warszawa 1989, s. 171 (przy wszystkich cytatach z tej publikacji w nawiasie podaje się pierwsze słowo tytułu oraz lokalizację).

${ }_{19}$ Tenże, Wschody $i$ zachody księżyca, Warszawa 1990, s. 36 (przy wszystkich cytatach z tej publikacji w nawiasie podaje się pierwsze słowo tytułu oraz lokalizację).
} 
[...] Budzę się umarły z podłym nastrojem nieboszczyka i z okropną męką zaczynam się reanimować [...] (Kalendarz, s 67);

[...] Jestem kompletnie załamany. [...] Jestem naprawdę wykończony (Kalendarz, s. 169);

[...] Najjaskrawszym objawem takiego stanu jest niechcenie. Coraz więcej rzeczy mi się nie chce, właściwie teraz mi się już niczego nie chce (Kalendarz, s. 250).

\section{2.}

[...] Brakuje mi również tematów oraz pomysłów literackich. Inni mają na kopy i życia im nie starcza, żeby zrealizować wszystkie. A ja nie znalazłem ani jednego konceptu, ani jednego pomyśluneczku, ani cienia gagu (Kalendarz, s. 225);

[...] Odrzuca mnie. Odrzuca mnie od beletrystyki. Z siłą silnika odrzutowego odrzuca mnie od roboty fabularnej (Wschody, s. 5);

[...] Nie piszą mi się zdania. Napotykam trudności, których nie umiem pokonać. Dawniej tego nie znałem (Wschody, s. 29);

[...] Wiem, że pisze mi się chudo, że ciągnę taką postną watę z kłęba nadzianego na patyk, co topniała w ustach do rozmiarów niewielkiej kropli bez smaku. Wiem, że pisze mi się dużo, ale bez zapachu, bez przypraw, bez witamin (Wschody, s. 205);

[...] Zapaść. Straszna zapaść. Okropne uczucie nicości. Nicości ze starości. A raczej nicości na starość. Wszystko, co człowiek zrobił, rozsypało się na pył, niewidoczny kurz, złe powietrze. [...] Zapaść okrutna, jakiej jeszcze nie znałem. Ja się starzeję i moje zapaści się starzeją (Wschody, s. 76);

[...] A ja chciałem tylko powiedzieć, że niefart teraz, dzisiaj, w tej chwili, w końcówce życia, że niefart mnie osłabia, tłumi we mnie wenę, zabija wiarę w siebie (Nowy, s. 58) ${ }^{20}$.

3.

[...] Oj Iwanie, Iwanie, dożyliśmy się na starość (Wschody, s. 18);

[...] Z ciężkim sercem zabieram się do pisania kolejnej nikomu niepotrzebnej książki. [...] natoczyłem do starego pióra starego atramentu, który nie wiadomo po co odnalazł się niedawno w rupieciach (Nowy, s. 5).

I można byłoby uwierzyć w prawdziwość przedstawianego przez literata wizerunku starca, gdyby nie jedna podstawowa cecha jego sylwicznej prozy, czyli autoironiczność. Tym bardziej, że podczas rozmowy z Beresiem Konwicki zaprzeczył, że miał jakiekolwiek problemy z pisaniem: „[...] Oooo! Byłbym tradycyjnym osłem literackim, gdybym twierdził, że męczę się przy pisaniu. Wcale się nie uskarżam! [...]"21.

Przywołana wypowiedź pozwala na postawienie hipotezy, że literat celowo założył maskę starca, która dała mu prawo do rozpoczęcia „literackiego oczyszczania” z kompleksów i obsesji nabytych podczas całego swojego 50-letniego życia. O sakramentalnej funkcji sylw oraz wywiadów świadczą zaś następujące wypowiedzi:

${ }^{20}$ T. Konwicki, Nowy Świat i okolice, Warszawa 1986, s. 58. (przy wszystkich cytatach z tej publikacji w nawiasie podaje się pierwsze słowo tytułu oraz lokalizację).

${ }^{21}$ S. Bereś, dz. cyt., s. 351. 
[...] Prawda to jest przedśmiertne rozgrzeszenie [...] (Nowy, s. 6);

[...] Rany boskie, jak to wolno idzie. Znudziłem się kompletnie tą jękliwą spowiedzią (Kalendarz, s. 57);

[...] W owym czasie albo może trochę później uprawiałem proceder, do którego trochę nijako mi się przyznać. Okradałem po prostu niemieckie transporty kolejowe [...] (Kalendarz, s. 26).

[...] — Proszę pana, mija już ósma godzina, jak rozmawiamy, a pan ciągle mi nie dowierza i jest w stosunku do mnie podejrzliwy. Przyznaję się jak na spowiedzi, że zawsze tęskniłem za tajemniczością²2.

Jak zaznaczył Tadeusz Sobolewski w jednym z wywiadów z Konwickim: „literaturę można porównać do spowiedzi”23. W odniesieniu do pisarstwa autora Kalendarza $i$ klepsydry przywołane porównanie nabiera dosłownego znaczenia, bowiem wyczuwalne jest w nim silne poczucie grzechu lub — jak ujął to sam Konwicki: „męka grzechem”. Wynika ona z „wniosków wyciągniętych z życiorysu” pisarza:

„[...] źródła tego poczucia winy [...] mogą wynikać z mojego rodowodu katolickiego, z tego katolicyzmu naszego kresowego, nadzwyczaj surowego i czasami antypatycznego nawet, który nas trzymał w garści przy pomocy szantażu grzechem. Żyliśmy w jakiejś obsesji lękowej”24.

Proces oczyszczania, tłumaczenia $\mathrm{z}$ „poczucia winy” nie zawsze — raczej bardzo rzadko - prowadził do wyjawienia przez Konwickiego prawdy, męczącej wewnętrznie tajemnicy. Można odnieść wrażenie, że artyście bardziej zależało na samym procesie dochodzenia do prawdy, niż jej objawieniu swoim interlokutorom, czy czytelnikom. Zaś do „przerywania narracji” Konwicki wykorzystywał atrybut starości, jakim jest degradacja pamięci:

\section{[...] A jak to było naprawdę? (Wschody, s. 46);}

[...] Jak to tam było pod Wilnem? Kiedy to było? Trzydzieści siedem lat temu. Ja już nie pamiętam. Tak właśnie zapytano starego wiarusa napoleońskiego: jak to było w 1812 roku pod Moskwą? A on na to: nic nie pamiętam, nic nie pamiętam. Pamiętam tylko, że było gorąco (Wschody, s. 52);

[...] Ja wiem, że dla pewnych ludzi ten lipcowy długi dzień to najdłuższy dzień w ich życiu. [...] A ja, nikczemny, ten właśnie dzień zapomniałem. Nigdy też o nim nie wspominałem w swojej pisaninie. [...] Zapomniałem nasz wspaniały zryw akowski z 1944 roku, roku zniesienia okupacji niemieckiej w moim kraju rodzinnym (Wschody, s. 53).

Oprócz zaburzeń pamięci, starzec Konwicki cierpiał również na inne nawyki charakterystyczne dla starszych ludzi, jak na przykład niecierpliwość lub dygresyjność podczas snucia opowieści. Dzięki temu swobodnie mógł omijać tematy dla siebie niewygodne, męczące, bolesne, przy jednoczesnym spełnieniu danej czytelnikom oraz

\footnotetext{
${ }^{22}$ Tamże, s. 254.

${ }^{23}$ T. Sobolewski, Jesteśmy wcią tacy sami, [w:] Nasze histerie, nasze nadzieje. Spotkania z Tadeuszem Konwickim, P. Kaniecki, Warszawa 2013, s. 40.

${ }^{24}$ Tamże, s. 40-41.
} 
rozmówcom obietnicy wyznania, bowiem opowieść o przeszłości, o tym, co się wydarzyło, zostaje jedynie „odroczona” ${ }^{25}$.

[...] Tak mi się nie chce tłumaczyć, tak mnie irytują te mimowolne samousprawiedliwienia [...] (Kalendarz, s. 57);

[...] Już, już. Już się zbliżam do pryszczatych oraz stalinowców. Wiem, że to jest ponętniejsze i bardziej bulwersujące. Co tam prawić o starych dziejach, w które i tak nikt nie wierzy (Kalendarz, s. 53).

Oprócz pojawienia się motywu starości w kontekście sakramentu spowiedzi sędziwy wiek dał Konwickiemu także prawo do snucia osobistych rozważań nad czasem i jego wpływaniu nie tylko na ludzi, ale także na ich wytwory, na przykład literaturę. Pisarz definiował „starość” poprzez trzy zjawiska, a mianowicie: „niemożność, „zdezaktualizowanie” oraz „zblaknięcie”.

„Niemożność” — należy identyfikować z pojawiającymi się wraz z wiekiem ograniczeniami fizycznymi, a „zblaknięcie” z zanikami pamięci. „Zdezaktualizowanie” zaś wiązało się z refleksjami starzejącego się pisarza. Prowadzone przez Konwickiego refleksje przede wszystkim dotyczyły literatury, jej recepcji, ale także minionych lat i aktualnych niegdyś problemów, które trudno zrozumieć młodszym pokoleniom:

[...] Nie mam żadnych podstaw do przypuszczeń, że za dziesięć lat ktoś sięgnie po moją książkę [...] (Kalendarz, s. 5);

[...] Gruzowisko rzeczy byłych i niebyłych. Co to kogo obchodzi. Co to mnie obchodzi (Kalendarz, s. 298);

[...] Kiedyś literatura rzeczywiście miała ogromne znaczenie, podczas gdy dziś jest ono znacznie przesadzone. [...] Na przykład dawniej bywali ludzie, którzy czytali Trylogię przez całe życie. Dziadek mojej żony, na przykład, przeczytał ją czterdzieści razy [...] A przypomnijmy sobie „tołstojowców”! Byli pisarze, którzy stwarzali rodzaj religii, i byli ludzie, którzy stawali się ich wyznawcami. A dzisiaj? Jesteśmy tak dalece zalani słowami, że one nic nie znaczą ${ }^{26}$;

[...] doszedłem do wniosku, że niemożliwe jest przekazanie klimatu myślowego, moralnego, nastroju jakiegoś czasu, jakiejś generacji. Czas, w którym dominuje dana generacja, ma swoją nerwicę, swoją psychozę, swój sposób patrzenia, oceniania, zachowywania się

[...] Utwór jest gorący, bulwersujący, dotyka wszystkich. Potem zmieniają się okoliczności cywilizacyjne i psychiczne, nadchodzi nerwica innego pokolenia i to przestaje być żywe, przestaje przemawiać. Nie wiadomo, czy kiedyś zmartwychwstanie $[\ldots]^{28}$;

[...] A ja piłuję tę trefną książkę, która w tym momencie rodzenia się już jest martwa. Jeśli zdobędziemy wolność, nikt nie zechce wracać pamięcią do złych i kiepskich lat [...] (Wschody, s. 210).

\footnotetext{
${ }^{25}$ P. Potasińska, Przektamania w autobiografii. „Prawdziwe zmyślenie” $i$ „łże-dziennik” (Hłasko i Konwicki), [w:] Strony autobiografizmu, red. M. Pieczara, R. Słodczyk, A. Wasilewska, Warszawa 2012, s. 138-145.

${ }^{26}$ S. Bereś, dz. cyt., s. 329.

${ }^{27}$ K. Bielas, J. Szczerba, dz. cyt.wickim, s. 21.

${ }^{28}$ Tamże, s. 147-148.
} 
Należy jednak zaznaczyć, że pomimo minoderyjnie prowadzonej gry z czytelnikami oraz swoimi rozmówcami Tadeusz Konwicki faktycznie podlegał procesowi starzenia. Mający 88 lat artysta ujrzał jednak w tym procesie pretekst do „spowiedzi” oraz sposób na odejście ze sceny artystycznej. Zaobserwowana na sobie przemijalność oraz faktycznie dotykające go problemy z pamięcią wpłynęły na wybór formy wypowiedzi literackiej, czyli sylwy współczesnej.

Wystarczy zapoznać się z ogólną definicją sylwy ${ }^{29}$, aby zrozumieć, że jej silne dążenie do fragmentaryczności pozwalało Konwickiemu na burzenie porządku linearnego w prowadzonych przez siebie narracjach. Było to ogromnym ułatwieniem dla pisarza, który wyjawił w jednym z wywiadów, że:

[...] Po prostu nie panuję już nad całością tak, jak kiedyśs panowałem. Do mojej prozy wkradają się pewne nieprecyzyjności, które już toleruję. Brak konsekwencji zaczyna być wynikiem erozji pamięci, a nie wyłącznie artystycznego zamiaru. I dlatego usiłuję tę erozję wykorzystać jako artystyczną metodę ${ }^{30}$.

Konwicki już w 1976 roku zaczął zdawać sobie sprawę, że przemija. Regularnie odnotowywane obserwacje na ten temat w „łże-dziennikach” doprowadziły go do pełnych, starczej goryczy stwierdzeń:

[...] Coraz cześciej moi przyjaciele chodzą do szpitala. Coraz częściej moi przyjaciele nie wracają ze szpitala [...] (Kalendarz, s. 98);

[...] Być. Być obecnym. Być na wierzchu. Ale przecież my już przeszliśmy do historii. Przeminęliśmy razem z naszym czasem, przez ten czas ulepieni, uformowani i skamieniali. Zamilczcie więc z honorem, chociaż dzisiaj już nikt nie pamięta, co to honor [...] (Wschody, s. 444);

[...] od jakiegoś czasu jestem w głębokiej zapaści, w okropnym dole. Nie chce mi się żyć. Nie chce mi się nic robić. I piszę dosyć nerwowo, bo ciągle mi się wydaje, że ginę. [...] Po prostu czuję, że przepadam. Jakieś dziwne myśli: Po co? Dlaczego? Komu? [...] Wie pan, to jest taki niesympatyczny rys, który pojawia się wraz z wiekiem. Coraz częściej łapię się na tym, że zrzędzę̨ ;

[...] Gdy się teraz sobie przyglądam, to myślę, że moja wewnętrzna wyporność, moja wewnętrzna potencja były zaprogramowane na - załóżmy — jakieś sześćdziesiąt lat. Na tyle to obliczam. A tu natura zrobiła sobie żarcik towarzyski; biologicznie dała mi szansę na dłuższe życie. [...] żyję dalej. W związku z tym wyłażą wszystkie niedogodności podeszłego wieku².

Tadeusz Konwicki milczał przez dziewiętnaście lat, tyle samo czasu zajął mu sam proces odchodzenia ze sceny artystycznej, który sfinalizowała wydana w 1995 roku,

\footnotetext{
${ }^{29}$ Sylwy współczesne to dzieła: „[... ] nie respektujące jednolitych zasad gatunkowych, odwołujące się do różnorakich wzorów, łączące elementy wywodzące się z różnych gatunków i tradycji literackiej, na przykład dziennika intymnego i narracji powieściowej poezji i prozy, eseju, monologu wewnętrznego. [...] choć fragmentaryczne w konstrukcji, stanowią kompozycyjną całość [...]”. (R. Nycz, Sylwa wspótczesna, [w:] Stownik terminów literackich, red. J. Sławiński, Wrocław 2008, s. 545).

${ }^{30}$ S. Bereś, dz. cyt., s. 212.

${ }^{31}$ Tamże, s. 360-361.

${ }^{32}$ K. Bielas, J. Szczerba, dz. cyt., s. 232.
} 
dążąca do formy aforystycznej sylwa Pamflet na siebie. Milknięcie znalazło więc i swoje odzwierciedlenie w sposobie konstrukcji utworu.

Prześledzenie leitmotivu starości w sylwach i autokomentarzach Konwickiego pozwala wysnuć wniosek, że artysta zatoczył w swoim życiu koło, powrócił do punktu wyjścia, bowiem za młodu przywdziewał kostium starca, a na starość sięgnął po literacką maskę. Doskonałą puentą spostrzeżeń są słowa samego pisarza, według którego „starość to negatyw dzieciństwa”.

Katarzyna Ossowska

\section{Old AGE, COMMONLY VIEWED AS “INABILITY, REGRESS, FADEDNESS", APPEARS AS A LEITMOTIV IN SYLVA'S ${ }^{33}$ TRIPTYCH aNd TADEUSZ KonwICKI's aUto COMMENTS}

\section{Summary}

Whole Tadeusz Konwicki's works have been strongly influenced by his own personal experiences. In his work Kalendarz $i$ klepsydra one can find the same motives, situations, figures and descriptions of nature. However, one of the most repetitive leitmotive's in his prose is ageing. In a very surprising way because of the fact that at the same time it is unpredictable and ironic, the author presents this topic in his autobiographical prose - that is in sylva's triptych consisted of Kalendarz i klepsydra, Wschody i zachody księzyca and Nowy Świat i okolice. It is quite an extraordinary situation taking into consideration the fact that during the publication of the first sylva Konwicki is fifty years old — is it the age when human starts thinking about death. That question will probably be left with no answer.

It is highly likely that such way of thinking about death and ageing appeared in his works because of the intensity of the experience he had gained before throughout his half of a century life. Maybe it is some kind of trick to achieve the advantage over the dialogue between an intelligent reader and himself as an author.

Ageing in Konwicki's works is multidimensional - it does not refer only to the physical ageing but also to the process of literary creation. Therefore the main purpose of this article is to collect, describe and categorise the most important topics and motives when Konwicki pretended to be old man.

Słowa kluczowe: Tadeusz Konwicki, starość, sylwa, dezaktualizacja

Keywords: old age, silva, regress

${ }_{33}$ Silva rerum (from Latin silva rerum — forest of things), polonized sylwa. 